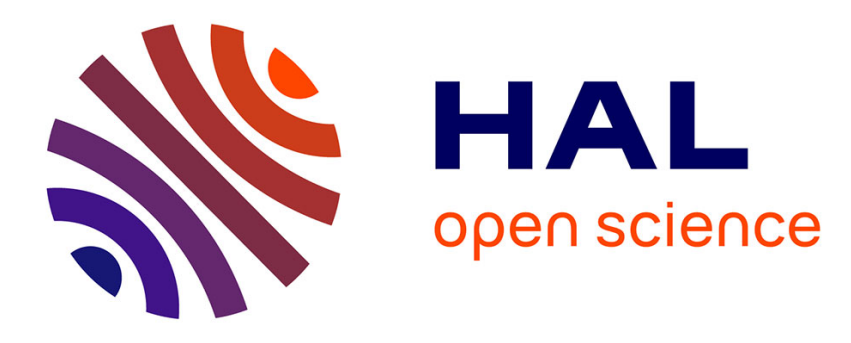

\title{
Procédés de prédétermination de surfaces sélectives. Application à la protection des photopiles
}

\author{
F. Papini, Refondini
}

\section{To cite this version:}

F. Papini, Refondini. Procédés de prédétermination de surfaces sélectives. Application à la protection des photopiles. Revue de Physique Appliquée, 1966, 1 (3), pp.237-237. 10.1051/rphysap:0196600103023700 . jpa-00242724

HAL Id: jpa-00242724

https://hal.science/jpa-00242724

Submitted on 1 Jan 1966

HAL is a multi-disciplinary open access archive for the deposit and dissemination of scientific research documents, whether they are published or not. The documents may come from teaching and research institutions in France or abroad, or from public or private research centers.
L'archive ouverte pluridisciplinaire HAL, est destinée au dépôt et à la diffusion de documents scientifiques de niveau recherche, publiés ou non, émanant des établissements d'enseignement et de recherche français ou étrangers, des laboratoires publics ou privés. 


\title{
PROCÉDÉS DE PRÉDÉTERMINATION DE SURFACES SÉLECTIVES. APPLICATION A LA PROTECTION DES PHOTOPILES
}

\author{
Par F. PAPINI et Mme REFONDINI
}

Laboratoire d'Héliotechnique de la Faculté des Sciences de Marseille.

Résumé. - Deux procédés mis au point au Laboratoire permettent l'étude des épaisseurs et du nombre de couches minces à déposer sur un support en vue de l'obtention d'une surface sélective imposée à l'avance. Ces deux méthodes sont la construction graphique et la simulation électrique. C'est à l'aide de la première que nous avons cherché à prédéterminer les épaisseurs des couches en vue de protéger les photopiles de la partie du spectre solaire inutile à leur fonctionnement. Pour cela nous avons choisi deux matériaux diélectriques à déposer en couches alternées ; nous avons tracé par constructions graphiques un réseau de caractéristiques dépendant uniquement de la nature des couches. Ce réseau est composé de 2 sortes de courbes. Les premières donnent le facteur de réflexion maximum par $2,4,6$ et 8 couches en fonction du déphasage des couches de numéro impair, et les secondes donnent le déphasage des couches paires en fonction de celui des couches impaires pour avoir ce facteur de réflexion maximum. L'utilisation de ce réseau permet de trouver d'une manière simple les coefficients de proportionnalité qui relient les différentes épaisseurs en vue de résoudre le problème donné, et cela par le tracé de droites de fonctionnement déterminées par la forme de la courbe du facteur de réflexion que l'on veut obtenir.

Abstract. - Two processes studied in our laboratory allow the study of the thicknesses and of the number of thin layers to be deposited upon a substrate, to obtain a selective surface determined in advance. These methods are : graphic construction and electrical simulation.

With the first method we tried to pre-determine the thicknesses of the layers to protect photocells from that part of solar spectrum which does not contribute to their response. To do this, we selected two dielectric materials, to be deposited alternately in thin layers ; we constructed graphically a system of characteristics which depends only on the nature of the layers. This system is composed of two kinds of curves. The first gives the maximum value of reflectivity for $2,4,6$ and 8 layers as a function of the phase of the odd layers, and the second gives the phase-shift of the even layers as a function of the phase of the odd layers, to obtain the maximum value of the reflectivity. The utilisation of this system gives, in a simple way, the coefficients of proportionnality which determine the thicknesses needed to resolve the particular problem. 